\title{
Correction to: Field evaluation of seven products to control cyanobacterial blooms in aquaculture
}

\author{
Riley P. Buley ${ }^{1} \cdot$ Catie Adams $^{1} \cdot$ Angelea P. Belfiore $^{1} \cdot$ Edna G. Fernandez-Figueroa $^{1} \cdot$ Matthew F. Gladfelter $^{1}$. \\ Brynne Garner ${ }^{1} \cdot$ David L. Straus ${ }^{2} \cdot$ Alan E. Wilson ${ }^{1}$ (I)
}

Published online: 9 August 2021

(C) Springer-Verlag GmbH Germany, part of Springer Nature 2021

\section{Correction to: Environmental Science and Pollution}

Research (2021) 28:29971-29983

https://doi.org/10.1007/s11356-021-12708-0

Dr. David L. Straus is added as seventh author for his Author Contributions under Conceptualization for introducing peracetic acid as a potential compound to selectively control cyanobacterial blooms in aquaculture.

Publisher's note Springer Nature remains neutral with regard to jurisdictional claims in published maps and institutional affiliations.

The online version of the original article can be found at https://oi.org/ $10.1007 / \mathrm{s} 11356-021-12708-0$

Alan E. Wilson

wilson@auburn.edu

David L. Straus

dave.straus@usda.gov

1 School of Fisheries, Aquaculture, and Aquatic Sciences, Auburn University, Auburn, AL 36849, USA

2 U.S. Dept. of Agriculture, Agricultural Research Service, Harry K. Dupree - Stuttgart National Aquaculture Research Center Stuttgart, Stuttgart, AR, USA 